\title{
In Brazil, basic stem cell research lags behind clinical trials
}

In the 1990s, Richard Burt injected people in the US with their own bone marrow stem cells and successfully treated a variety of autoimmune disorders, including multiple sclerosis and lupus. So it seemed obvious to him that the same approach could be used to reset the overactive immune system in people with another autoimmune disease: type 1 diabetes. If the therapy was performed early enough in the disease course, Burt thought, it could help people go off insulin-replacement therapy by enabling them to generate insulin-producing beta cells again before irreversible damage to the pancreas set in.

He drew up a clinical protocol and shopped it around to colleagues close to home, but "endocrinologists in America had no interest in it whatsoever," recalls Burt, head of immunotherapy at Northwestern University's Feinberg School of Medicine in Chicago. "The focus in America has always been intensive insulin therapy and embryonic stem cells [to treat diabetes], and this is neither one of those things."

Burt did, however, find a receptive audience for his innovative therapy in Júlio Voltarelli at the University of São Paulo (USP) School of Medicine of Ribeirão Preto in Brazil. In 2003, he handed off the trial design to Voltarelli and his colleagues, and, with the blessing of ethics committees at both the local University Hospital and the federal Ministry of Health, the Brazilian team treated 23 people newly diagnosed with type 1 diabetes with stem cells taken from their own blood. As the researchers had hoped, the majority of the study subjects managed to maintain normal blood sugar levels for years after the treatment without having to continue taking insulin injections (JAMA 301,1573-1579, 2009). Off the back of that first trial success, Voltarelli and Burt are currently treating more young diabetics with their approach—in Ribeirão Preto, but, notably, in Chicago, St. Louis and Paris, too.

The diabetes trial is not the only one using stem cells to have found its footing in Brazil. In 2007, for example, Brazilian doctors launched the world's largest stem cell clinical trial to date: a 1,200-person study testing whether bone marrow cells can reverse the damage found in four heart conditions. The first arm of the study, for people with Chagas disease, is now complete; according to trial investigator Antonio Carlos Campos de Carvalho of the Federal University of Rio de Janeiro (UFRJ), the treatment did not show clinical benefit. However, pioneering adult stem cell trials are ongoing in Brazil for respiratory disease, stroke, epilepsy, spinal cord injury and anemia, among other ailments.
Meanwhile, the country has produced some noteworthy stem cell findings in the basic science arena. Last month, for example, UFRJ's Stevens Rehen reported the derivation of the first Brazilian reprogrammed cell lines from healthy donors and someone with schizophrenia, too (Cell Transplant. doi:10.3727/096368911X600957, 2011). Rehen and his colleagues also released software to help automate image counting of pluripotent stem cells, which has been downloaded close to 500 times to date (Integr. Comput. Aided Eng. 18, 91-106, 2011).

That may sound like the metrics of a vibrant research community. But, as Rehen point out, his lab alone produces around half of all papers in Brazil related to pluripotent stem cells, whereas most of the stem cell field continues to focus on applying adult stem cells. "Brazil has managed to advance a lot in the preclinical and clinical area," says Carvalho, who coordinates the National Cell Therapy Network, which counts 52 labs across five Brazilian states. "But we're lagging behind in the basic science."

To remedy that, the Brazilian government introduced several measures to give the stem cell field a boost. In 2005, the country passed the Biosafety Act, which allowed researchers to derive human embryonic stem cells from donated surplus embryos stored for at least three years at assisted reproduction clinics. The measure was quickly challenged by religious factions, but, with backing from scientific groups and patient advocacy organizations, the Brazilian Supreme Court ultimately upheld the legislation in 2008.

\section{Confidence interval}

Legalizing human embryonic cell research "was a major event-not only in terms of shaping the research of the field and determining what the regulations were going to be, but also in terms of inspiring confidence and motivating the field," says Dominique McMahon, a postdoc at the University of Toronto who wrote a paper last year surveying the regenerative medicine landscape in Brazil (Regen. Med. 5, 863-876, 2010).

Yet, despite the legislation, "most of the groups continue to work with adult, not embryonic, stem cells," says Mayana Zatz, director of USP's Human Genome Research Center. Indeed, it wasn't until August of this year that researchers, led by the USP's Lygia Pereira, reported the first establishment of an embryonic stem cell line, called BR-1, from a Brazilian person (Cell Transplant. 20, 431-440, 2011). Pereira says she has since derived three more embryonic stem cell lines, but because all four come from

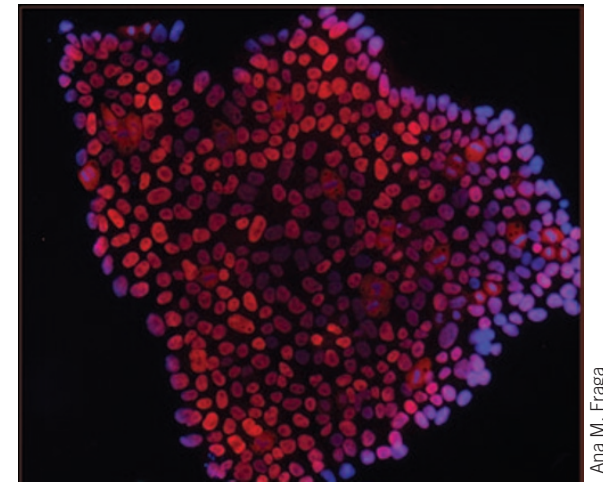

Embryonic development: The BR-1 cell line.

private fertility clinics, which tend to cater to Brazil's ethnically European elite, they do not come close to representing the rich genetic diversity of the country. That doesn't bode well for translational research, she says, because "we want to work now to make a library of cells that will represent the Brazilian genetic diversity that can be used in pharmacogenomic studies and drug screening programs."

For that, Pereira, in collaboration with Rehen, hopes to create several hundred induced pluripotent stem (iPS) cell lines through the Brazilian National Laboratory of Embryonic Stem Cells (LaNCE). The lab, which has sites at UFRJ and USP, was established in 2009 as part of the government's 25-million-Brazilianreal (\$15 million) initiative to create eight Cell Technology Centers across the country. Parts of LaNCE-which, despite its name, focuses on all pluripotent stem cells-are operational, thanks to state and federal grants. But plans to build a new facility for the center have been delayed, in part because the Brazilian Development Bank (BNDES) only delivered on its promised 6-million-real contribution earlier this year. "Everything took a very long time," says Pereira, who expects construction to begin later this month. "It was frustrating, but we're now celebrating the arrival of the money."

The Brazilian stem cell community faces other budget issues, however, especially following the presidential election last year in which longtime stem cell supporter and former health minister José Serra lost to current President Dilma Rousseff. "We are not sure what the priority of stem cell research is under the new administration," says Pereira. That's a problem, adds Rehen, because "we need to guarantee constant funding opportunities for the stem cell field in Brazil in the next years. If not, everything regarding stem cells-both adult and pluripotent-built in the last years will not stay."

Elie Dolgin 